\title{
A house-shaped shrine in a Carolingian setting, as depicted in the oldest portrait of St Columba in Cod Sang 555
}

\author{
Peter Yeoman ${ }^{1}$
}

\begin{abstract}
This paper will consider the oldest known image of St Columba, contained within a copy of Adomnán's Vita sancti Columbae, created around the middle of the 9th century in the monastery at St Gallen in Switzerland. Columba established a confederation of monasteries in Britain and Ireland, centred on his great foundation at Iona, before his death in AD 597. His fame spread to the Continent, in relation to a network of Carolingian monasteries with Scotto-Irish links, resulting in a persistent devotion to certain Irish saints, the context for which is outlined here. Rather than simply being an illustration in support of the manuscript, the image affirms the significance of Columba to the culture of St Gallen more than 200 years after his death. Most remarkably, a 'house-shaped' shrine - of possible Insular origin - features in the church setting of this image, and this is discussed in relation to the possible origins and identification of this object, possibly as a Columban reliquary. Whereas this paper focuses on the materiality of the image and especially on the extraordinary representation of the reliquary, an art historical assessment of the image is also essential to achieving a full understanding. As this is outwith the skills of the present author, the art historical significance will be fully explored in a forthcoming, accompanying paper by Prof Jane Geddes.
\end{abstract}

\section{THE EUROPEAN CULTS AND LEGACY OF SS COLUMBANUS AND GALL}

By sometime soon after 850 , the monks of the St Gallen scriptorium created a new copy of Adomnán's Vita sancti Columbae (Life of St Columba), copied from an original possibly made on Iona a few years after he (d 704) authored this work in about 697 , possibly as a centennial memorial to his illustrious predecessor. The strong and persistent devotion of the Carolingian monks of St Gallen to Columba can be traced back to the mission to Europe led by his namesake Columbanus (c543-615). 'Little Columba' had left his monastery at Bangor, Co Down, around 590. He founded monasteries governed under his own austere Irish rule at Annegray, Luxeuil, and Fontaines in France, and latterly at Bobbio in Lombardy, where he died in 615.
During the 7 th century, the disciples of Columbanus founded other monasteries in what is now France, Germany, Belgium and Switzerland (Farmer 2011). The Columbanians were set apart from their contemporary brethren in the monasteries of Merovingian France and in the Cisalpine area, with their peculiar tonsure and strongly penitential lifestyle. This brought Columbanus into conflict with Pope Gregory, especially over the computation of the date of Easter (Medieval Histories 2015). When Columbanus moved to Bobbio in 614, his disciple Gall stayed behind in Switzerland, living as a hermit until he died $c$ 650. A monastery was founded $c 719$ dedicated to St Gall on the site of his hermitage and place of burial, where he was venerated as the evangelist of the region.

The city of St Gallen is located in north-east Switzerland, where the later cathedral and its

\footnotetext{
12 Craighall Bank, Edinburgh EH6 4RW
} 


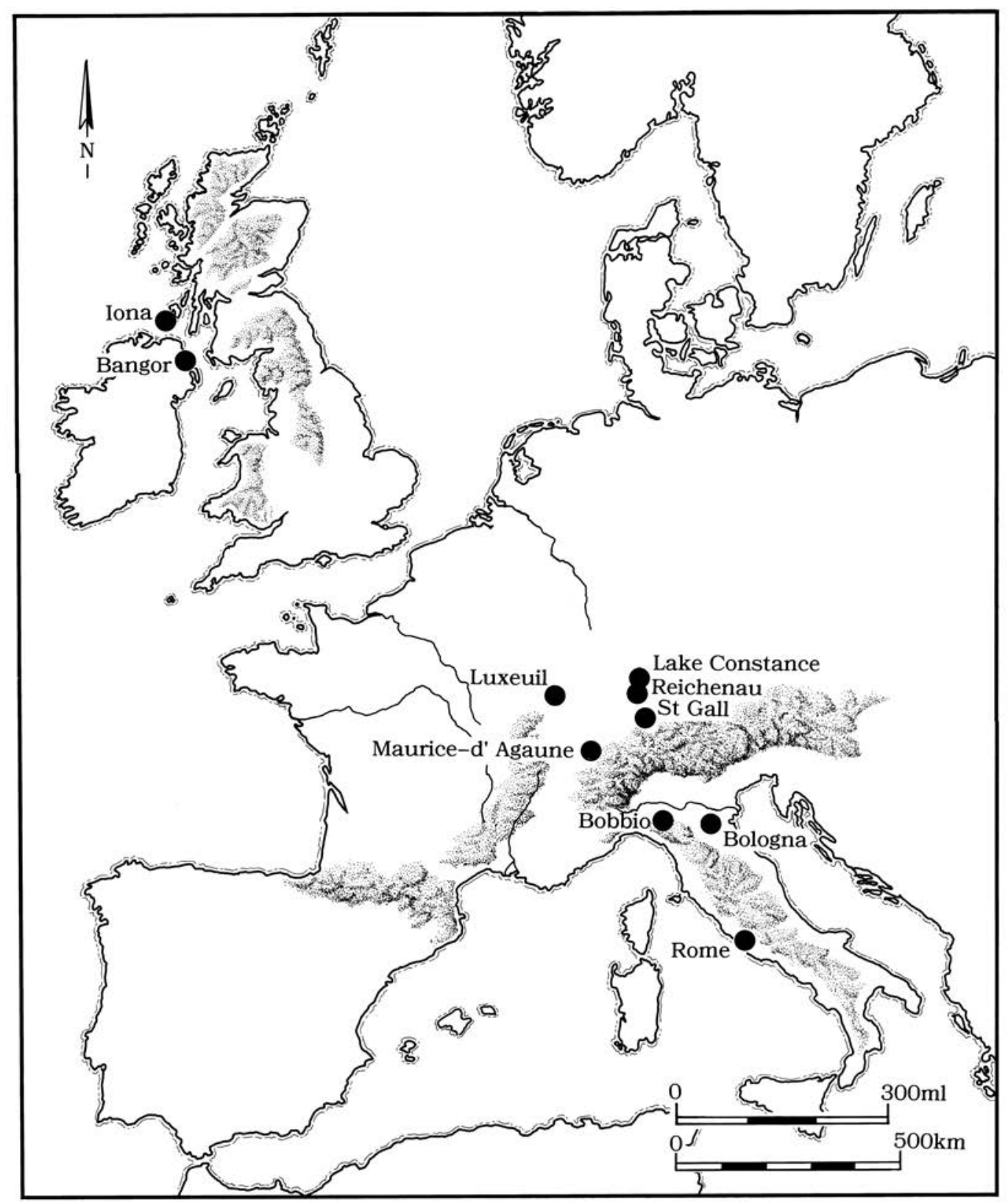

ILLUS 1 Map of key places mentioned in the text 
remarkable high Baroque library of about 1760 are now a World Heritage Site. The earliest treasures of the library include a large body of Irish manuscripts of the 7th-9th centuries, along with the illuminated manuscripts of the St Gallen School of the 9th and 11th centuries. It became one of the great centres of learning of the early medieval period, attracting monks from all over Europe (Tremp et al 2007: 77). The library today houses the famous Plan of St Gall, created for Abbot Gozbert between 819-30, which depicts an idealised Benedictine monastic complex (ibid: 12). The Plan promotes the strong contemporary interest in how architecture could best serve the liturgical veneration of the cult of saints and their relics, as shown below in how the St Columba image demonstrates a concern for the reality of worship (Palazzo 2011: 100 and $\mathrm{J}$ Geddes pers comm). The real - rather than idealised - church of St Gallen had been rebuilt $c 830$ by Abbot Gozbert to include a new reliquary crypt for the relics of their patron saint (Crook 2000: 137).

By the mid-700s the abbey had abandoned Irish strictures in favour of the Benedictine rule, but the special relationship with Irish monastic culture continued (Duft \& Meyer 1954: 12). The early sources related to the monastery reveal a mingling of Irish and Continental names among the monks. Monks from Ireland and what is now Scotland participated in this cultural movement, to revitalise what they considered to be the debased practices of some Continental monasteries. Once established, new waves came as pilgrims to the tombs of their saintly predecessors, some en route to Rome, while others were attracted as scholars (ibid: 29). Their numbers were periodically swollen by refugees escaping the Viking raids which targeted Insular monasteries from the 790s onwards, bringing with them books of Irish origin. This helped engender an awareness of Columba as an important saint, along with a strong interest in and knowledge of Columba's Iona as another great monastery. This can be seen in the poem written $c 825$ by Walahfrid Strabo (d 849), when dean of St Gallen, concerning the martyrdom of Abbot Blathmac of Iona, in which Strabo had a first-hand account of the massacre from one or more of the monks who had escaped the carnage, and in which he expressed a knowledge of Columba's relics. And, at St Gallen it was believed that there were only three degrees of separation between Columba and Gall - Columba was Comgall's teacher, Comgall taught Columbanus, who in turn was Gall's superior (Sharpe 1995: note 205). That Columba was the spiritual ancestor of Gallus is considered by Picard to be the key to understanding the significance of Columba's cult at St Gallen (Picard 2002: 98). Insular manuscripts continued to be deposited at St Gallen; for instance, in 841, Marcus, an Irish bishop returning from a pilgrimage to Rome, visited and decided to remain at St Gallen, gifting them a number of books (Reeves 1857: xxii).

\section{ADOMNÁN'S VITA COLUMBAE AT ST GALLEN}

Among the books carried abroad was the earliest surviving copy of Adomnán's Vita Columbae, the Life of St Columba, created by Abbot Dorbbéne in the Iona scriptorium $c 700$, originally held at the early monastery of Reichenau on Lake Constance in Germany, 32 miles $(52 \mathrm{~km})$ north-west of St Gallen, now preserved in the Stadtbibliothek, Schaffhausen, Switzerland. The Schaffhausen manuscript is conventionally designated as MS A (Sharpe 1995: 236), and is considered to be the source of all the Continental versions, possibly having arrived on the Continent in the 8th century via the monasteries of Péronne and Fosses in northern France, which were part of the familia of monasteries related to the Irish saint Fursa (Picard 1998: 4). MS A reached Reichenau c 850, and soon after was copied in the St Gallen monastic scriptorium, where it is catalogued today as St Gallen, Stiftsbibliothek, Cod Sang 555: Vita sancti Columbae (e-codices 2015). Here the St Gallen scribes created the 'oldest witness' to the shorter (abridged) recension, removing episodes specific to the Irish context, proper names and geographical data, while retaining chapters with universal appeal for the edification of the $\mathrm{St}$ Gallen monks (Picard 2001: 222). The text of this 


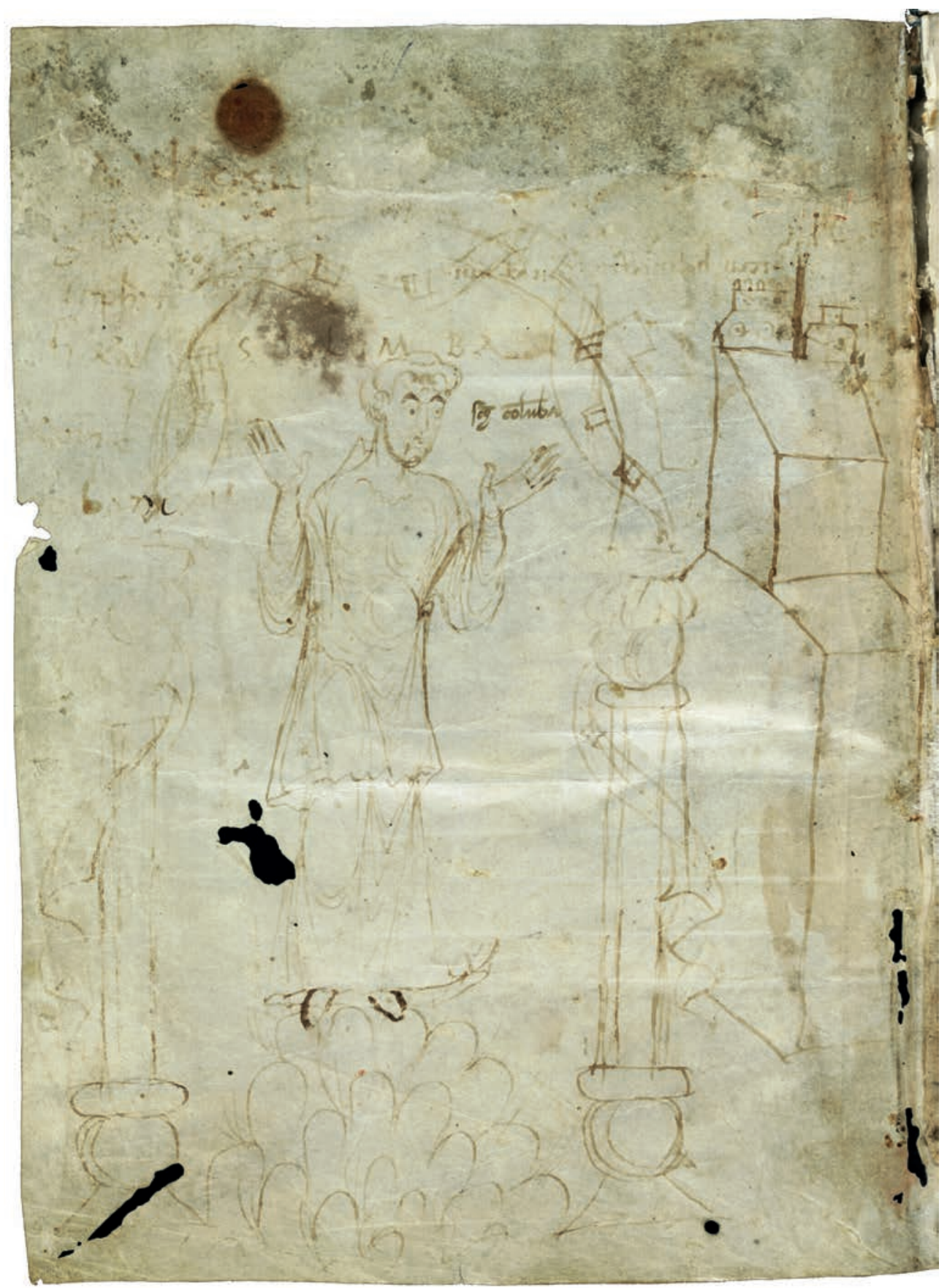

ILlus 2 The image labelled as St Columba on the last page, page 166, of the St Gallen copy of Vita sancti Columbae created in the mid-9th century, Cod Sang 555 (@ Stiftsbibliothek St Gallen) 
copy was further disseminated through Germany and Austria to become the most popular version of the Vita (ibid: 221).

\section{THE OLDEST PORTRAIT OF ST COLUMBA}

This manuscript contains an image of Columba on the last page (166, see Illus 2), which was first reproduced by Reeves in his major edition of the $\mathrm{A}$ text published in Dublin in 1857, who designated the St Gallen copy as Codex S (Reeves 1857: plate 5 facing xxviii). It is important to note that, as the illustration is on the last page, two pages after the end of the manuscript, it could have been added at a later date. The oldest catalogue of the St Gallen library, created in the time of Abbot Grimald between 841-72, lists a copy of the Vita sancti Columbae in codice uno, then a newly created work (Duft \& Meyer 1954: 13). The fact that Cod Sang 555 fills the whole of the codex makes this identification likely (Picard 2002: 96). The St Gallen manuscript is written in Latin in Carolingian script, and seems to have been well used in the library, being mentioned repeatedly in later catalogues (Duft \& Meyer 1954: 53). It is a small quarto parchment manuscript, originally of 81 folios (Esposito 1910: 75).

To date there has been little discussion of this image, being simply described by von Euw (2009: 357-8) in the e-codices entry. The image was well-drawn in pen and black ink, now faded with some localised damage, filling most of the page which measures $1900 \mathrm{~mm} \times 1400 \mathrm{~mm}$. This may have been a sketch which was never fully worked up, and could even have been copied from another image (R Sharpe \& R Gem pers comm). The saint stands central to and almost filling a round-headed arch, presumably representing a chancel arch or the arched entry to a side chapel. The arch is supported on a pair of polygonal columns, with rounded bases and capitals, all festooned with a fluttering fabric drape, like a ribbon, wound loosely around and uniting the arch and columns. The foliage forms carved on the capitals could be the artist's take on the acanthus leaf motifs commonly found on Carolingian capitals.

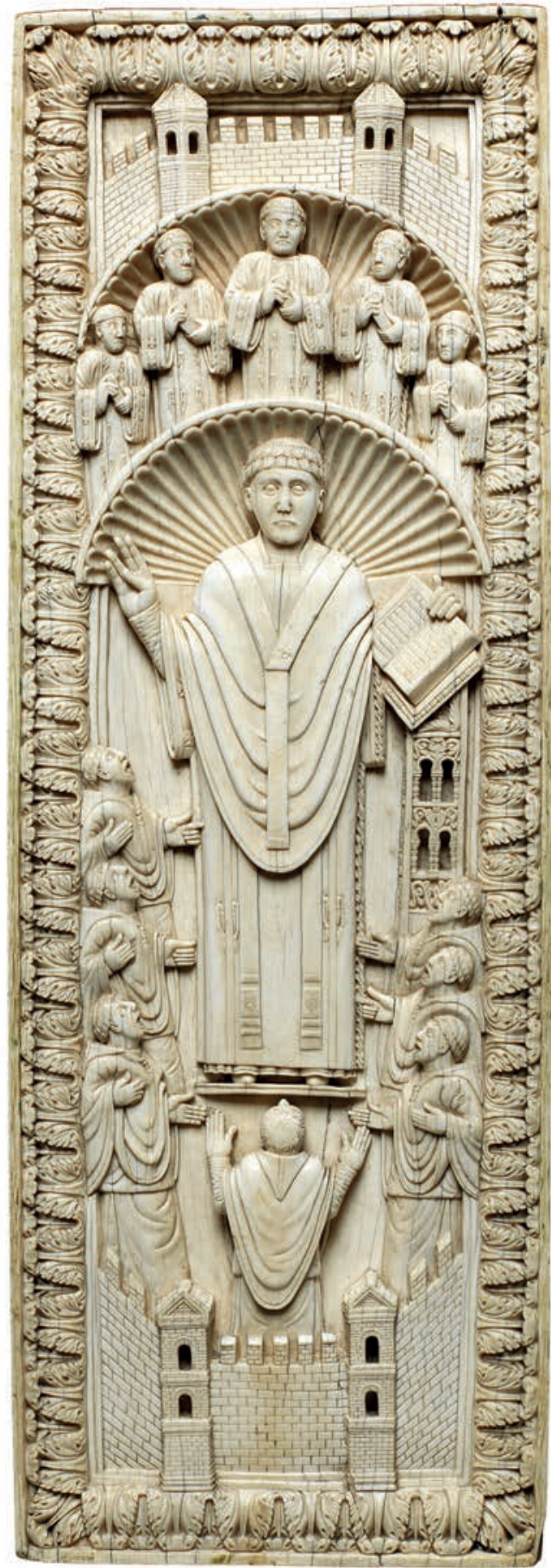

ILLus 3 Ivory panel from a book cover, Carolingian 10th century, depicting a bishop about to celebrate Mass among his Choir. M 12-1904 (C) The Fitzwilliam Museum, Cambridge) 
Columba is shown without an aura, with a coronal tonsure and a cluster of three curls on his wrinkled forehead, standing with arms raised to either side in the Orans position, addressing a congregation who are located in the foreground, in front of the chancel arch, represented simply by about 20 egg-shaped outline heads. A useful parallel for this scene may be the 10th-century Carolingian ivory book panel from Lotharingia (the area of modern Lorraine in France), now in the Fitzwilliam Museum (see Illus 3). This shows a bishop officiating at what may be the introit at the beginning of Mass; here no altar is in sight and the bishop stands among the clergy in the choir, with his right hand raised while with the left he is holding a book on a lectern, facing a monastic choir who seem to be chanting or singing. The St Gallen image may similarly represent a stage in the celebration of the Mass. Columba is dressed in a full-length alb, which comes down to his protruding feet, over which he wears a knee-length tunic or dalmatic, with a straight lower hem, such as might be worn more appropriately by a deacon, rather than the chasuble which would normally be worn by a priest celebrating Mass (Miller 2014: 247; R Gem pers comm). These un-ornamented vestments are simply delineated to represent deep folds of light cloth in a classicising Carolingian style. He is named in display capitals written above his head $-S$. COLVMBAE. It has been suggested that these words are in the genitive case 'of Columba', and therefore a preceding word, such as VITA, is missing ( $\mathrm{R}$ Gem pers comm), although there is no sign of this on the drawing. The identification of the subject is reiterated in a later minuscule script as Scs Coluba "with both words having a long horizontal stroke indicating that they are abreviations of sanctus and Columba respectively' (Dr P Lenz pers comm), added to the drawing $c$ 1200, which demonstrates the prolonged nature of the interest of St Gallen monks in the cult of Columba. Close examination of the page appears to show the ghost of further writing above and to the left of the arched enclosure. At the author's request this has been examined under ultra-violet light by Dr Lenz at Stiftsbibliothek, St Gallen; the results were inconclusive (Dr P Lenz pers comm).

\section{HOUSE-SHAPED SHRINES IN THE IMAGE}

Of particular interest, on the right hand side of page 166 (Illus 4), is the depiction of a pair of what seem to be small reliquary containers, one of which at least appears to be a houseshaped shrine (HSS). This is a rare if not unique image from this time of a HSS shown within a liturgical context. The pair of reliquaries sit atop a lectern-shaped stand, which itself sits on a tiered base, immediately to the left of the saint, which the viewer sees partly side-on. The two reliquaries stand just above Columba's head height, occupying the same space as him within a chapel or the presbytery of a church. The HSS is the larger of the two and is viewed face-on, with hipped gables visible at either end. There are three tiers of decoration; the lower of which features three applied mounts, each with a central dot likely to represent a glass stud. A row of what seems to be three smaller mounts is indicated above this on the sloping roof-lid, surmounted by a ridge topped with a row of possibly five upright, oval decorative fittings. A hinged carrystrap fitting may be indicated at the left end. There is an inaccuracy in the drawing, however, in that the 'hips' rise from the lower register and should properly belong with the sloping roof of the middle register (C Bourke pers comm). A vertical object, which could be a candle (or a later mark), separates the HSS from the smaller casket to the right. This object is less distinct, and seems to be have a rounded top with a square shaped handle above. This could even be another HSS.

A total of at least 12 complete or almost complete HSSs of Irish and Pictish manufacture survive, along with fragments of others, dating from the 7th to 9th centuries (Blindheim 1984; Quast 2012: 59), as 'an Insular version of a common continental form' (Ryan 1989: 129). In the north Alpine area, Quast has defined a further two groups of these caskets, namely an Anglo-Saxon group, along with a third being a Mediterranean-Gallic-Frankish group (Quast 2012: 119). House-shaped shrines are representations in miniature of the tomb or shrine of a saint, and were generally small enough to be held in the palm of one hand. The HSSs were made in monastic workshops like 


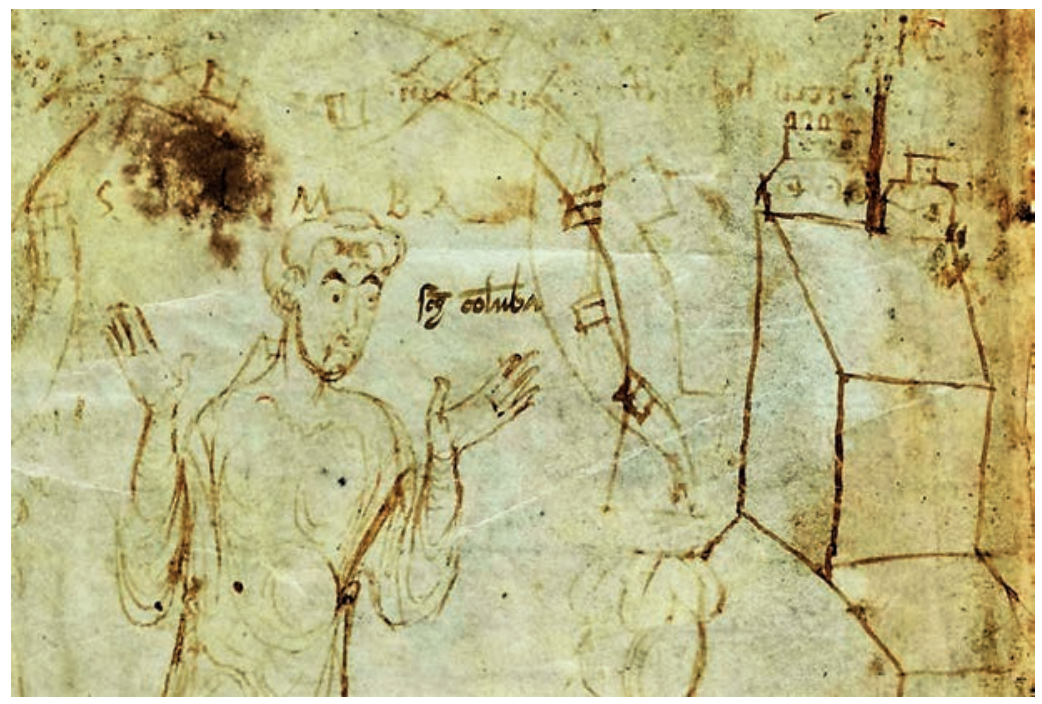

ILLus 4 St Columba with the liturgical objects displayed on the lectern to his left (detail from Illus 2 enhanced by the author)

those tentatively identified at Iona Abbey from the excavated evidence of moulds and other metalworking debris (Campbell \& Maldonado 2016: 90), their very act of creation being a form of religious devotion. They are usually interpreted as portable shrines, designed for carrying small pieces of a saint's bones in procession, or out into the community for the sanctification of laws and oaths (Caldwell 2001: 269). The precious materials used in making these boxes honoured and emphasised the sacred nature of their contents (Smith 2012: 156). Alternatively, a small casket like this could have served as a portable chrismal containing holy oil, or else as a pyx for the consecrated host brought to the sick and dying. Lacking any precise evidence of function, such as the inscription on the AngloSaxon casket from Mortain, France, which states that it was indeed a chrismal (O'Donoghue 2011: 86 ), it is otherwise impossible to be definite about function, and of course they may have had multiple uses over a long life. These complex composite objects were usually fabricated around the core of a wooden box covered with gilded metal plates, with applied metalwork decoration, and prominent gable finials joined by a roof ridge bar with inturned animal head terminals.
Sometimes only the front was decorated as they were designed to be carried hung around the neck on a strap, which was attached to either end of the box, and the back not seen (Ryan 1989: 129). The trapezoidal roofs were hinged for opening to give access to the objects contained therein.

\section{PARALLELS FOR THE SHRINES SHOWN IN THE IMAGE}

This form of portable shrine may have originated in western Europe, where Quast (2012: 59) has listed at least 19 surviving examples in his Mediterranean-Gallic-Frankish group, including for example the 7th-century Merovingian reliquary casket from Saint-Maurice d'Agaune (Rudenbach 2013: 91). However, they are distinctively different in design, in that they lack the distinctive circular and rectangular applied mounts and ridge treatment, commonly used on the Insular examples. The development of HSSs in different regions was taking place in parallel, and further study of this inter-relationship is required. The 7th-century early HSS from Bobbio, a monastery of the Columbanus familia, is remarkably similar to the example from 
Clonmore, however, aspects of the manufacture of the Bobbio example caused Ryan to conclude that 'this was made abroad under Irish direction' (Ryan 1990: 110).

An unprovenanced Caroligian reliquary from the upper Rhine has a ridge formed of interlocking animal heads, which, when sketched, could possibly resemble the ridge on the larger HSS in the St Gallen illustration (Quast 2012: Tafel 12 ), as, at a push, can also be said regarding the ornate interlocking ridge on the HSS from Enger (ibid: Tafel 14). However, the fronts of these are decorated with geometric arrangements of multiple cabochons which in no way resemble the object in the Columba sketch. As far as the three-over-three arrangement of possibly circular mounts is concerned, a broad similarity can be seen in the front of the Ennabeuren HSS (ibid: Tafel 1), although this features stamped multiple roundels, displaying heads similar to Roman

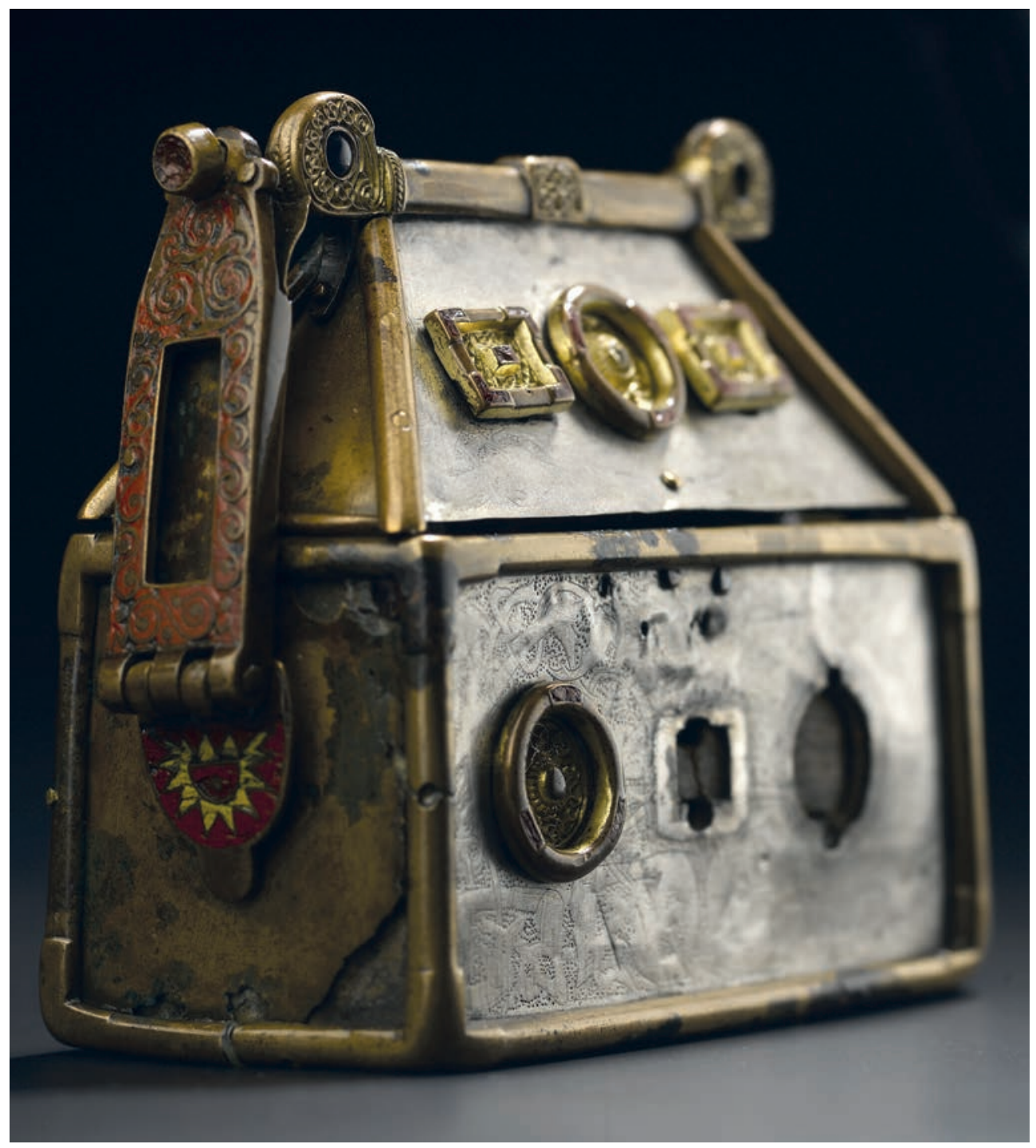

Illus 5 The Monymusk reliquary (@ Trustees of the National Museums of Scotland) 


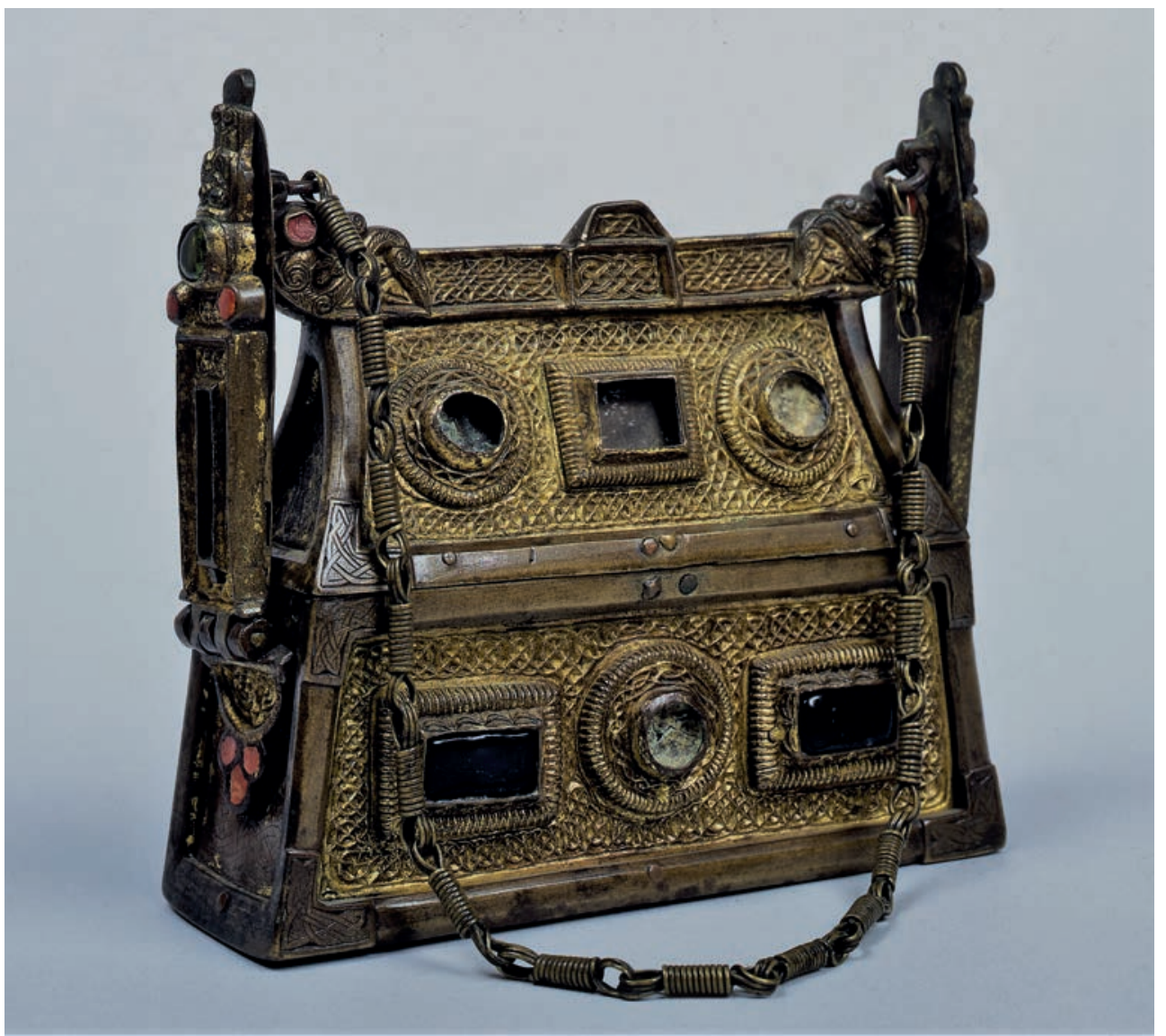

Illus 6 The Bologna house-shaped shrine () Museo Civico Medievale, Bologna, Italy)

emperors, rather than applied mounts common to the Insular examples.

Lacking convincing Continental parallels, there are two Insular HSSs that might provide parallels to the one in the St Gallen illustration. The three-over-three arrangement of mounts is also seen in the Monymusk reliquary, as well as in the reliquary now in the University Museum in Bologna, Italy.

Both of these have alternating circular and rectangular applied mounts, decorated with coloured enamel work which originally contained glass studs (Youngs 1989: 140). Another Insular HSS which found its way to Italy is in Abbadia San Salvatore in Tuscany, which still contains bones attributed to Columbanus (ibid: 134). This has only a pair of circular mounts on the front side, and a single mount on the roof.

\section{DISCUSSION}

The illustration on the last page of the Cod Sang 555 is important in its own right as the oldest known illustration of St Columba, helping us understand the lasting devotion to him, as well as to other Irish saints, in central Europe, resulting from waves of immigration by peregrini monks originating from Irish and Pictish monasteries. Due to the filial link, Columba was seen as the spiritual ancestor of Columbanus and Gallus; and, thanks to the powerful influence of the 
monastery of St Gallen, the cult of Columba was spread further through the region, where he was commemorated in the liturgical texts of some great churches (Picard 1998: 11). Adomnán may not have been overstating the case when he claimed that Columba's cult had reached beyond the Alps (Vita III: 23), even in his biographer's lifetime.

In terms of dating the portrait, Jane Geddes has commented that a 'survey of the St Gallen illustrations shows that [the] St Columba [portrait] clearly belongs to this scriptorium environment, with several strong comparisons from the 9th-10th centuries' (Geddes pers comm). It is therefore possible that the sketch could have been added up to a 100 years after the completion of the Vita manuscript in the mid-9th century.

The Irish manuscripts at St Gallen and Reichenau, together with the Insular HSSs now held at San Salvatore and Bologna (as well as a 7th-century HSS at Bobbio) (ibid: 134-40; Columbanus 2015), show that the Irish monks travelled not only with books but also with other liturgical objects, together with precious relics, in their satchels. This has been demonstrated by the discovery of an inscribed parchment fragment originally used to wrap small corporeal relics of Columba, Adomnán and Columba's teacher, Finnian, found at the abbey of Saint-Maurice d'Agaune, which is close to one of the main Alpine passes on the borders of Switzerland, France and Italy. The wrapping was inscribed with the names of the three saints written in Irish minuscule text dated to the 8 th century (Smith 2015: 241).

The artist of the sketch was a monk who would have drawn on inspiration from things around him. The architectural setting in which he placed the saint may be derived from his own church of St Gallen, and the same applies to his depiction of the pair of reliquaries placed atop the altar in what could even be the chapel dedicated to St Columba in that church. The idealised church of the St Gallen Plan features a proliferation of altars and side chapels, much of this being driven by the need to accommodate the cults of saints as an essential component of the architecture of the Carolingian Renaissance (Crook 2000: 80).
If Columba is shown celebrating Mass in a church or chapel facing the congregation, then the relic stand would have been located on the right-hand side of the altar, in a place often reserved for relics or burials of great distinction. It may be that the scene records the display of relics on a special feast day - that of Columba himself - as it would have been only on such a day that these relics would have been displayed, either on an altar or else on a raised horizontal beam (Smith 2012: 158). An arrangement of Continental house-shaped shrines and other reliquaries are shown suspended from a beam in the frontispiece to the $c 1100$ manuscript of Thiofrid of Echternach's Flores epytaphii sanctorum (a discussion of the cult of relics) (Ó Cróinín 2013: 240). In the St Gallen image, the reliquaries seem to be perched uncomfortably on the apex of a sloping lectern top, however, difficulties in interpretation may arise here due to non-representational perspective, where a surface which appears to slope may in fact be horizontal - and in that case it is more likely that what appears as a lectern is actually an altar. Jane Geddes has pointed out how this is graphically illustrated in the earliest image of an altar reproduced at St Gallen, 820-30, in the St Gallen Psalter, Zurich Zentralbibliothek, MS C 12, f53v (e-codices 2017). Because of the incorrect perspective in this image, the top of the altar appears to slope, while the framework underneath is covered with embroidered cloths, which may well correspond to what is being expressed in the Cod Sang 555 image. This product of the same scriptorium, using similar artistic techniques, explains the appearance of the altar in the Columba picture (Geddes pers comm).

The artist monk is likely to have been depicting real objects, relics and reliquaries which formed part of the monastic treasury of St Gallen specifically related to Columba, familiar to the artist, and of such liturgical importance as to warrant their inclusion in the drawing. There was nothing random or accidental in his selection of objects to be included in the scene, which strongly indicates a link between them and the saint. And here we see a perfect example of the concept of presentia, whereby 


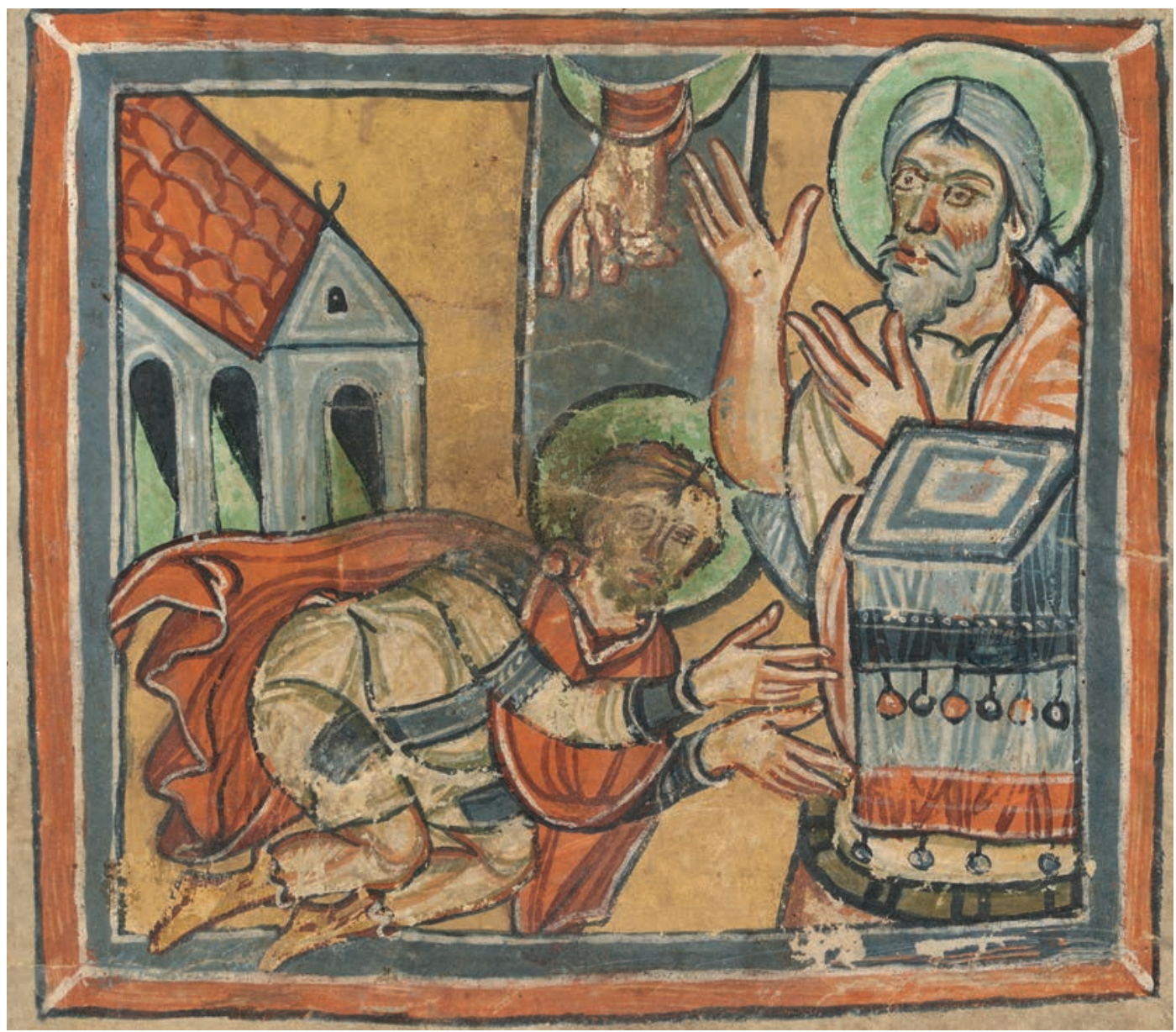

ILLus 7 An altar shown in non-representational perspective, similar to the altar in the Columba portrait. St Gallen Psalter c 830. (ㄷ Zürich Zentralbibliothek, MS C 12, f53r)

the saint was considered to be simultaneously present in his relics as well as being in Heaven (Crook 2000: 17). It can therefore be suggested that amongst the treasures of the monastery was at least one HSS, bearing a similarity to the one of Insular origin that ended up in Bologna. There is mention in Cod Sang 339 p6, in an entry in a Calendar and Sacramentary dated to around 1100, that the abbey church of St Gallen possessed relics of Columba (Duft \& Meyer 1954: 30). Were it true that the reliquaries shown in the image contained relics of the saint featured in this devotional image, it is certainly the case that the shrine is no longer to be found at St Gallen.
This author considers that the closest parallel for the HSS in the image is the Bologna shrine. This reliquary was created in a monastic workshop in Ireland or Pictland sometime around 800, and was eventually carried to the Cisalpine area by monks seeking a new home, where there was an interest in their native ascetic monastic culture and in the familiar cults of their saintly fathers. The original Continental home of the Bologna HSS is unknown; could it once have held a relic of St Columba, treasured in the sanctuary of the abbey church of St Gallen? The luxurious quality of the Bologna shrine would certainly befit its association with one of the greatest saints of the 
age. While this is speculation, one thing that this image allows us to be certain of is that the saint of Iona was fully absorbed into the culture of the Carolingian monastery of St Gallen. And from an archaeological perspective, this image is helpful in informing our impoverished understanding of the contemporary liturgical use of HSSs within the Irish and Pictish Church, where these sacred objects may have been displayed in a similar manner within the now long-lost sanctuaries of the earliest important churches.

\section{ACKNOWLEDGEMENTS}

The author is pleased to acknowledge the support of the Society of Antiquaries of Scotland who kindly provided an Angus Graham Award, which enabled the travel and research for this paper. The examination of the image at the St Gallen Stiftsbibliothek was kindly facilitated by the Stiftsbibliothekar Dr Cornel Dora. The author is most grateful to Dr Cormac Bourke, Dr Richard Gem, Dr Philipp Lenz, Prof Richard Sharpe and to Dr Julia Smith, for providing expert comments on this paper. Essential improvements and advice were generously given by Prof Jane Geddes and another anonymous reviewer.

\section{REFERENCES}

Andenmatten, B, Ripart, L, Mariaux, P-A \& Brero, T (eds) 2015 L'abbaye de SaintMaurice d'Agaune 515-2015. Gollion: Editions Infolio.

Bagnoli, M, Klein, H, Mann, C \& Robinson, J (eds) 2011 Treasures of Heaven: Saints, Relics and Devotion in Medieval Europe. London: British Museum Press.

Blindheim, M 1984 'A house-shaped Irish-Scots reliquary in Bologna', Acta Archaeologica 55: $1-54$.

Caldwell, D 2001 'The Monymusk Reliquary: the Breccbennach of St Columba?', Proc Soc Antiq Scot 131: 267-82.

Campbell, E \& Maldonado, A 2016 Russell Trust Excavations on Iona led by Charles Thomas, 1956-63. Unpublished data structure report. University of Glasgow.
Carey, J, Herbert, M \& Ó Riain, P (eds) 2001 Studies in Irish Hagiography: Saints and Scholars. Dublin: Four Courts Press.

Columbanus 2015 Examination of the Bobbio Reliquary/Chrismal. https://columbanus2015. wordpress.com/2013/06/28/examinationof-the-bobbio-reliquarychrismal/. Accessed August 2017.

Crook, J 2000 The Architectural Setting of the Cult of Saints in the Early Christian West c. 3001200. Oxford: Oxford University Press.

Duft, J \& Meyer, P 1954 The Irish Miniatures in the Abbey Library of St Gall. Olten: Urs GrafVerlag.

e-codices 2015 St Gallen, Stiftsbibliothek / Cod Sang 555 - Vita sancti Columbae, p166. http:// www.e-codices.unifr.ch/en/csg/0555/166/0/ Sequence-583. Accessed November 2015.

e-codices 2017 Zürich, Zentralbibliothek / Ms C 12 - Psalterium Gallicanum with Cantica / f53r. http://www.e-codices.unifr.ch/en/zbz/ C0012/53r. Accessed January 2017.

Esposito, M 1910 'Hiberno-Latin Manuscripts in the Libraries of Switzerland I', Proceedings of the Royal Irish Academy 28C: 62-95.

von Euw, A 2009 Die St. Galler Buchkunst vom 8. bis zum Ende des 11. Jahrhunderts (Vol 2). St Gallen: Verlag am Klosterhof.

Farmer, D H The Oxford Dictionary of Saints (5 rev edn) online version $2011 \mathrm{http}: / /$ www.oxfordreference.com.connect.nls. uk/view/10.1093/acref/9780199596607. 001.0001/acref-9780199596607-e-362. Accessed November 2015.

Hourihane, C (ed.) 2011 Insular and Anglo-Saxon Art and Thought in the Early Medieval Period. Pennsylvania: Penn State Press for the Index of Christian Art, Dept of Art \& Archaeology.

Medieval Histories 2015 Columbanus 6152015. http://www.medievalhistories.com/ columbanus-615-2015. Accessed November 2015.

Miller, M 2014 Clothing the Clergy: Virtue and Power in Medieval Europe, c 800-1200. Ithaca: Cornell University Press.

Ní Chatháin, P \& Richter, M (eds) 2002 Ireland and Europe in the Early Middle Ages: Texts and Transmission. Dublin: Four Courts Press. 
Ó Cróinín, D 2013 'Willibrord und die Früe Angelsüchsische Missionierung Kontinenateuropas' in Stiegmann, C et al (eds) Credo: Christianisierung Europas in Mittelalter, Band 1 Essays, 239-49. Petersberg: Imhof Verlag.

O'Donoghue, N 2011 'Insular Chrismals and House-Shaped Shrines in the Early Middle Ages', in Hourihane, C (ed.) Insular \& AngloSaxon Art and Thought in the Early Medieval Period, 84-91. Pennsylvania: Penn State Press for the Index of Christian Art, Dept of Art \& Archaeology.

Palazzo, E 2011 'Relics, Liturgical Space, and the Theology of the Church', in Bagnoli, M et al (eds) Treasures of Heaven: Saints, Relics and Devotion in Medieval Europe, 99-107. London: British Museum Press.

Picard, J-M, 1998 ‘Adomnán’s Vita Columbae and the cult of Colum Cille in continental Europe', Proceedings of the Royal Irish Academy 98C No. 1: 1-23.

Picard, J-M 2001 'The cult of Columba in Lotharingia (9th-11th centuries): the manuscript evidence', in Carey, J et al (eds) Studies in Irish Hagiography: Saints and Scholars, 221-36. Dublin: Four Courts Press.

Picard, J-M 2002 'Schaffhausen Generalia 1 and the textual transmission of Adomnán's Vita Columbae on the continent', in Ní Chatháin, $\mathrm{P}$ \& Richter, M (eds) Ireland and Europe in the Early Middle Ages: Texts and Transmission, 95-102. Dublin: Four Courts Press.

Quast, D 2012 Das merowingerzeitliche Reliquienkästchen aus Ennabeuren. Mainz: Schnell \& Steiner.

Reeves, W 1857 The Life of St Columba, Founder of Hy, written by Adamnan. Dublin and Edinburgh: Edmonston and Douglas. https:// archive.org/details/vitasancticolumb00adam. Accessed November 2015.
Rudenbach, B 2013 'Von der Wirkmacht heiliger Gebeine', in Stiegmann, $\mathrm{C}$ et al (eds) Credo: Christianisierung Europas in Mittelalter, Band 1 Essays, 87-93. Petersberg: Imhof Verlag.

Ryan, M 1989 'Church metalwork in the eighth and ninth centuries', in Youngs, S (ed.) The Work of Angels: Masterpieces of Celtic Metalwork 6th-9th centuries $A D, 125-30$. London: British Museum Press.

Ryan, M 1990 'Decorated Metalwork in the Museo Dell' Abbazia, Bobbio, Italy', Journal of the Royal Society of Antiquaries of Ireland 120: 102-11.

Sharpe, R 1995 Adomnán of Iona: Life of St Columba. Harmondsworth: Penguin.

Smith, J 2012 'Portable Christianity: Relics in the Medieval West (c 700-1200)', Proceedings of the British Academy 181: 143-67.

Smith, J 2015 'Les reliques et leurs étiquettes', in Andenmatten, B, Ripart, L, Mariaux, P-A \& Brero, $\mathrm{T}$ (eds) L'abbaye de Saint-Maurice d'Agaune, 515-2015, 221-57. Gollion: Editions Infolio.

St Gallen, Stiftsbibliothek, Cod Sang 555: Vita sancti Columbae. http://www.e-codices.unifr. ch/en/list/one/csg/0555. Accessed November 2015.

Stiegmann, C, Kroker, M \& Walter, W (eds) 2013 Credo: Christianisierung Europas in Mittelalter, Band 1 Essays. Petersberg: Imhof Verlag.

Tremp, E, Huber, J and Schmucki, K (Horelent, J trans) 2007 The Abbey Library of St Gall, (translated from German). St Gallen: Stiftsbibliothek.

Youngs, S (ed.) 1989 Work of Angels: Masterpieces of Celtic Metalwork 6th-9th centuries $A D$. London: British Museum Press. 
